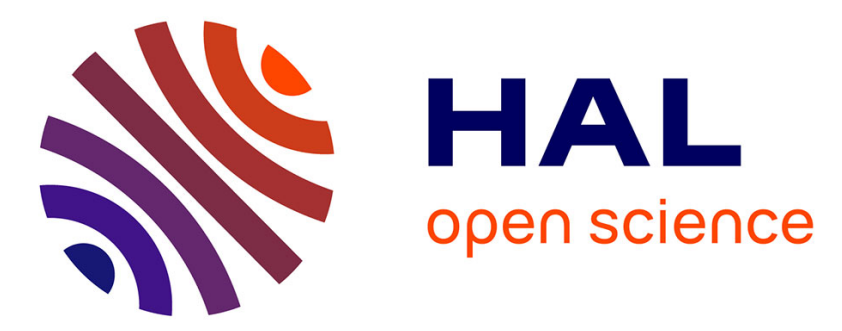

\title{
Dyslexic readers and saccade computation: effects of reading exposure and visuo-perceptual constraints
}

Stéphanie Bellocchi, Josette Mancini, Marianne Jover, Andrea Huau, Alain Ghio, Carine André, Stéphanie Ducrot

\section{To cite this version:}

Stéphanie Bellocchi, Josette Mancini, Marianne Jover, Andrea Huau, Alain Ghio, et al.. Dyslexic readers and saccade computation: effects of reading exposure and visuo-perceptual constraints. ESCoP Conférence XVIII, Aug 2013, Budapest, Hungary. ESCOP, pp.108-109, 2013. hal-01510227

\section{HAL Id: hal-01510227 \\ https://hal.science/hal-01510227}

Submitted on 1 Feb 2022

HAL is a multi-disciplinary open access archive for the deposit and dissemination of scientific research documents, whether they are published or not. The documents may come from teaching and research institutions in France or abroad, or from public or private research centers.
L'archive ouverte pluridisciplinaire HAL, est destinée au dépôt et à la diffusion de documents scientifiques de niveau recherche, publiés ou non, émanant des établissements d'enseignement et de recherche français ou étrangers, des laboratoires publics ou privés. 


\title{
Dyslexic readers and saccadle computation: effects of reading exposure and visuo-perceptual constraints
}

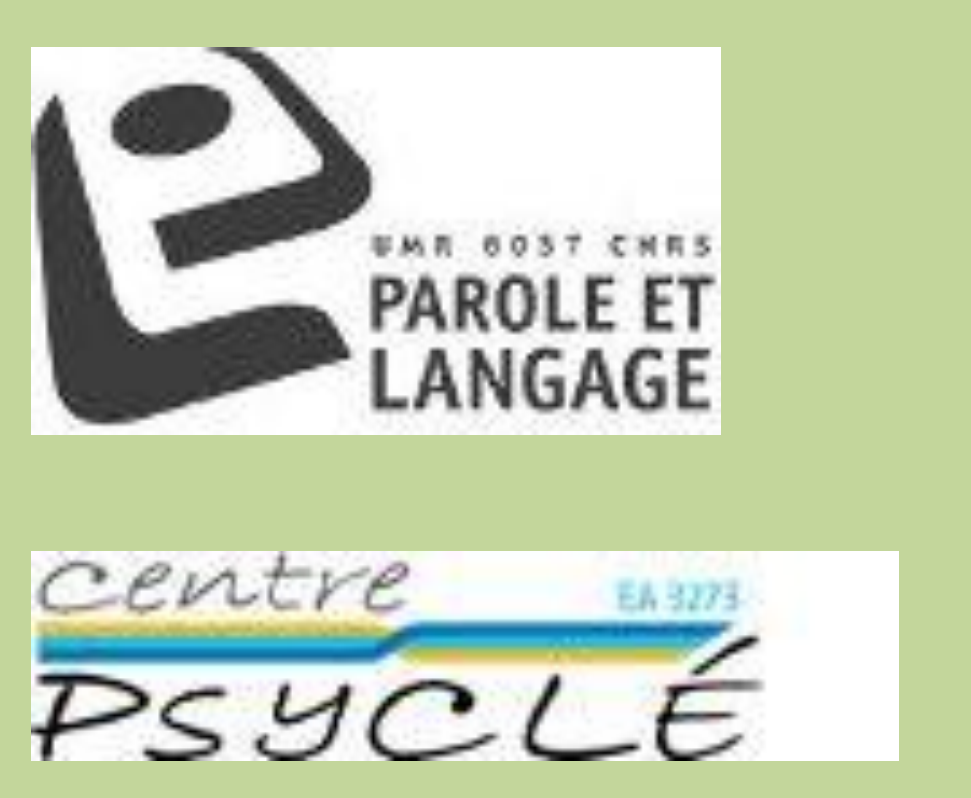

\author{
S. Bellocchi ${ }^{1,2}$, J. Mancini ${ }^{3}$, M. Jover ${ }^{2}$, A. Huau ${ }^{2}$, A. Ghio ${ }^{1}$, C. André1 ${ }^{1}$ S. Ducrot ${ }^{1}$ \\ ${ }^{1}$ Aix-Marseille Université, CNRS, LPL UMR 7309, 13100, Aix en Provence, France \\ ${ }^{2}$ Aix-Marseille Université, PsyCLE EA 3273, 13621, Aix en Provence, France \\ ${ }^{3}$ APHM, Hôpital de la Timone, CERTA, 13385, Marseille, France
}

corresponding author: stephanie.bellocchi@univ-amu.fr

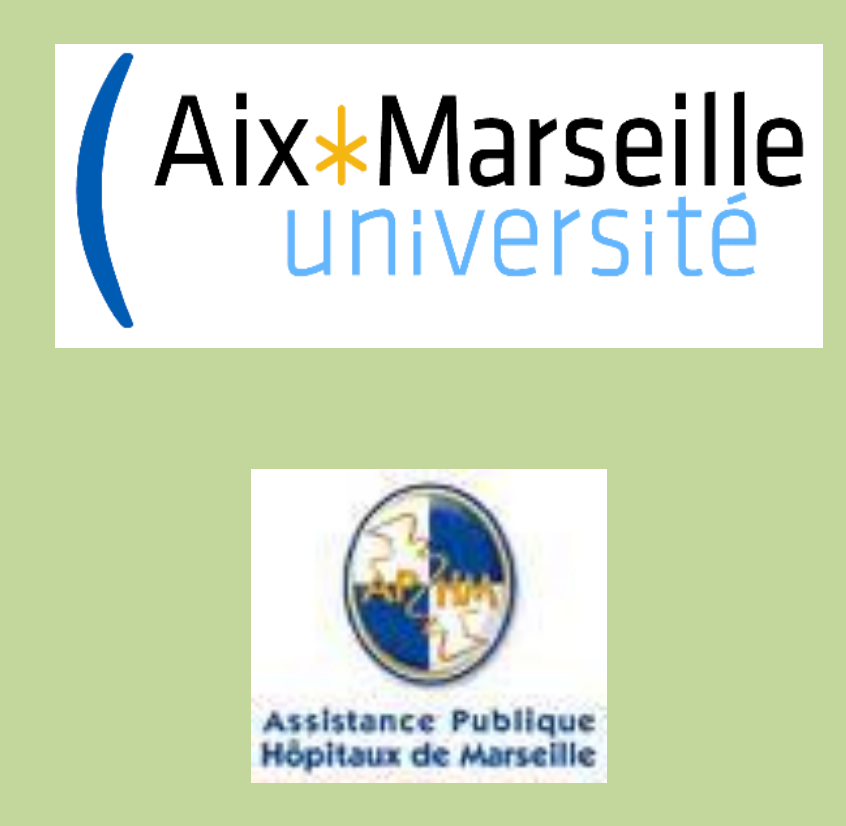

Some findings suggest the presence of preferred landing position (PLP) effects in children who are learning to read. Recently it has been shown that, in children from first to fifth grade, stimulus location has a strong effect on oculomotor development and lexical-decision time, in both central and parafoveal vision (Ducrot et al., 2013). The establishment of the PLP, which seems to be due to an eye-guiding mechanism based on a perceptual low-level processing, could also be influenced by print exposure.

How does saccadic programming develop in children with reading impairment?

As it is known, when no sensory and intellectual deficits can explain reading and/or writing disorders and when adequate instruction and socio-cultural opportunities are available but fail to result in an adequate level of performance, developmental dyslexia is diagnosed.

AIM OF THE PRESENT STUDY: the present study examines whether reading exposure/impairment and visuo-perceptual characteristics of the stimulus affect saccade computation.

\section{Methods}

\section{Participants}

$\checkmark 20$ dyslexic children (D) (CA: $m=125,56$; ds= 12,93 months; RA: $m=91,02$; ds $=10,73$ months) $\checkmark 25$ unimpaired reading-level controls (RL) (CA: $m=83,48$; $d s=7,34$ months; RA: $m=86,04$; ds $=6,31$ months)

$\checkmark 25$ unimpaired chronological-level controls (CA) (CA: $m=121,44 ; \mathrm{ds}=8,31$ months; RA: $\mathrm{m}=91,02 ; \mathrm{ds}=10,73$ months)

\section{Resulits}
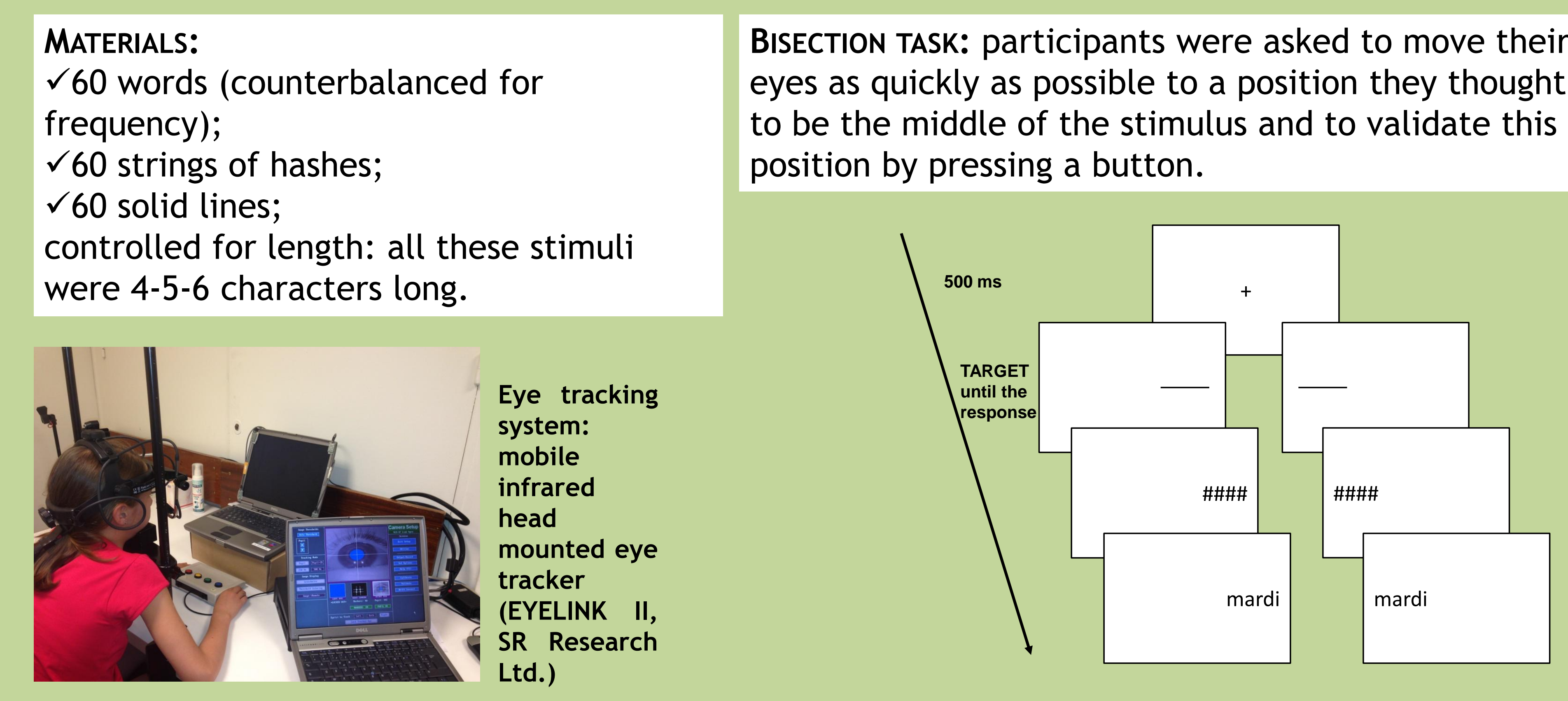

SACCADE SIZE: stimulus type * visual field * group $\left[\mathrm{F}_{(4,134)}=7,13 ; p<.001\right]$
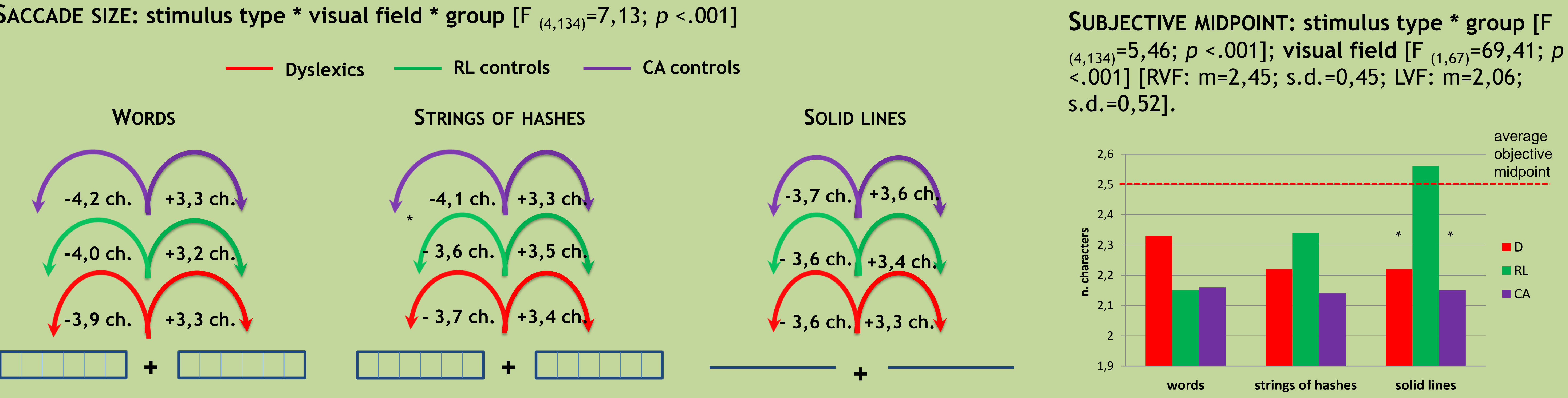

SACCADE LATENCY: stimulus type $\left[\mathrm{F}_{(2,134)}=199,20 ; p<.001\right]$ [words: mean $=169,85 ;$ std.e. $=2,40 \mathrm{~ms}$; strings of hashes: mean= $174,92 \mathrm{~ms} ;$ std.e. $=2,41 \mathrm{~ms} ;$ solid lines: mean= 204,09; std.e.= 2,67 ms]; group $\left[\mathrm{F}_{(2,67)}=18,04 ; p<.001\right]$ [D: $\mathrm{m}=178,85 ;$ std.e. $=4,21 \mathrm{~ms} ; \mathrm{RL}: \mathrm{m}=200,66$; std.e. $=3,76 \mathrm{~ms} ; \mathrm{CA}: \mathrm{m}=169,36 ;$ std.e. $=3,76$ $\mathrm{ms}]$.

\section{Discussion}

$\checkmark$ First of all, the most important result of the study shows a saccade-size asymmetry between left and right presentations, even if the asymmetry was more pronounced for CA-controls than for dyslexics and RL-controls. Moreover, within CA-controls group, the asymmetry was more marked for discrete stimulus (words and string of hashes) than for continuous one (solid lines) (Ducrot \& Pynte, 2002). However, dyslexics and RL-controls show a more marked asymmetry for linguistic (words) than for non-linguistic stimuli (strings of hashes and solid lines) $\rightarrow$ dyslexics show a pattern of results similar to RL-controls.

$\checkmark$ Longer initial saccade latency was found for continuous stimuli. Furthermore, RL-controls reveal longer saccade latency compared to dyslexics and CA-controls who show a similar pattern $\rightarrow$ dyslexic readers seem to show normal saccadic programming.

$\checkmark$ With regard to the subjective midpoint, like adult readers, CA-controls show no differences between type of stimuli (Ducrot \& Pynte, 2002). On the contrary, RL-controls show differences with regard to the type of stimulus suggesting that this strategy is going to be developed by young children.

$\rightarrow$ In conclusion, this study suggests that, regarding words, the basic oculomotor metrics of saccade landing positions are already well developed during the $1^{\text {st }}$ grade of print exposure (McConkie et al., 1991); however this is not true for non-linguistic/discrete stimuli; $\rightarrow$ dyslexia is associated with an accurate saccadic programming even if characterized by a delay with regard to the landing position pattern. 